\title{
Kolektyvinio bulgarų ir lietuvių tapatumo bruožai: lyginamoji studentų požiūrio analizè
}

\author{
DALIA SENVAITYTÉ \\ Vytauto Didžiojo universitetas, K. Donelaičio 52, LT-44248 Kaunas \\ El. paštas: d.senvaityte@hmf.vdu.lt
}

\begin{abstract}
Straipsnyje, remiantis $2010 \mathrm{~m}$. atlikto empirinio tyrimo duomenimis, aptariami kolektyvinio (tautinio, kultūrinio ir religinio) bulgarų ir lietuvių tapatumo bruožai, jų raiška tarp studentų. Atskleidžiami svarbiausi išryškejję bulgarų ir lietuvių tapatumo konstravimo bei raiškos panašumai ir skirtumai.
\end{abstract}

Raktažodžiai: bulgarai, kolektyvinis tapatumas, lietuviai, religingumas

\section{IVADAS}

Bulgarija, kaip ir Lietuva, yra sąlyginai nauja Europos Sajungos šalis. Lietuva yra ES nare nuo 2004 m. gegužès 1 d., Bulgarija - nuo 2007 m. sausio 1-osios. Nuo 2004 m. abi šios šalys yra ir NATO narès. Be to, abiejų šalių istorija kelis dešimtmečius taip pat buvo panaši. Lietuva 1940 m. ir nuo 1944 m. iki 1990 m. buvo okupuota Sovietų Sąjungos. Bulgarija, nors formaliai ir nebuvo viena iš penkiolikos Sovietų Sąungos respublikų, tačiau po jos „,išvadavimo“ 1944 m. pateko ị itin stiprią (bene didžiausią iš vadinamojo komunistinio bloko šalių) Sovietų Sąjungos įtakos zoną, iš kurios pradejjo vaduotis tik iširus Sovietų Sąjungai (1). Lietuvos ir Bulgarijos istorijos paralelès vienos ir kitos šalies istorinejje atmintyje matomos ir kalbant apie daug senesnius laikus nei XX amžius. Abi valstybės didžiuojasi savo sena didinga istorija, senomis valstybingumo tradicijomis, yra patyrusios ne vieną valstybingumo praradimą ir atgavimą.

Šalys sąlyginai panašios ir tuo, kad abi yra nedidelès valstybės, turinčios negausų gyventojų skaičių. Lietuvos Respublikos plotas yra 65,3 tūkstančiai km² , gyventojų skaičius, Statistikos departamento duomenimis, 2009 m. šiek tiek viršijo 3 mln. 300 tūkstančių žmonių. Bulgarija, būdama nedidelè Europos valstybè, savo plotu (maždaug 111 tūkstančių km²) beveik dvigubai yra didesnè už Lietuvos teritoriją. Gyventojų Bulgarijoje taip pat yra dvigubai daugiau nei Lietuvoje - šiek tiek daugiau nei $7 \mathrm{mln}$. (2). Etniniu atžvilgiu abi šalys gana homogeniškos: maždaug 84 \% Lietuvos gyventojų sudaro lietuviai, 6,1 \% - lenkai, 4,9 \% - rusai, atitinkamai

(1) Panaši XX a. antrosios pusès istorija būdinga praktiškai visoms vadinamosioms „Rytų Europos“ šalims. Šių šalių padètis Europoje panaši ne tik savo istorija, bet ir tam tikru specifiniu santykiu su likusiąja „Europa“.

(2) $2010 \mathrm{~m}$. „The World Factbook“ duomenimis, pagal plotą Bulgarija yra 104 šalis pasaulyje, pagal gyventojų skaičių - 98; Lietuva pagal plotą - 122, pagal gyventojų skaičių - 130 (prieiga per internetą: https://www.cia.gov/index.html). 
maždaug 84 \% Bulgarijos gyventojų sudaro bulgarai, 9,4 \% - turkai, 4,7 \% - čigonai (romai) (3).

Minètos aplinkybės paskatino panagrinèti bulgarų kolektyvinį identitetą ir palyginti ji su Lietuvos gyventojų kolektyvinio tapatumo (tautinio, kultūrinio, religinio) konstravimo ypatumais, išsiaiškinti pagrindinius šalių gyventojų kolektyvinio identiteto konstravimo bei raiškos panašumus ir skirtumus.

Tiek bulgarų, tiek lietuvių kolektyvinis identitetas, kaip socialinis konstruktas, buvo ir yra kintantis ir priklauso nuo skirtingų istorinių aplinkybių. Bulgarų kolektyvinis tapatumas visų pirma formavosi pabrèžiant bulgarų unikalumą jų artimiausių kaimynų - turkų ir graikų - atžvilgiu, su kuriais santykiai neretai buvo probleminiai (4). Atitinkamam lietuvių kolektyviniam tapatumui formuotis didžiausią ịtaką turèjo santykiai su lenkais.

Šio straipsnio objektas - kolektyvinis bulgarų ir lietuvių tapatumas. Tyrimo tikslas - atskleisti bulgarų studentų kolektyvinio (tautinio, religinio ir kultūrinio) tapatumo ypatumus ir palyginti juos su lietuvių studentų analoginio tapatumo ypatumais. Visų pirma nagrinejjamas tautinis tapatumas, tačiau, kadangi jis glaudžiai susijęs su kultūriniu ir religiniu tapatumu, $\mathfrak{i}$ tautinio tapatumo tyrimo lauką ịtraukiama ir kultūrinio bei religinio tapatumo analizė.

Tyrimo tikslas sąlygojo ir tam tikrus darbo uždavinius: remiantis teorine bulgarų kolektyvinio identiteto specifikos analize, parengti klausimyną ir apklausti bulgarų studentus; gautus rezultatus palyginti su atitinkamos lietuvių studentų apklausos rezultatais; išryškinti pagrindinius bulgarų ir lietuvių studentų kolektyvinio identiteto panašumus ir skirtumus. Tyrimo metodai - anketinè apklausa bei lyginamoji rezultatų analizè.

Tapatumas (tiek tautinis, tiek kultūrinis ar religinis) laikomas kintančiu socialiniu kultūriniu konstruktu, priklausančiu nuo transakcijų su „kitų“ tapatumų žmonėmis, jo šaknys - istorinès. Straipsnyje tautiškumas suprantamas kaip kolektyvinis tapatumas, besiremiantis tariamos bendros kilmès, giminystès suvokimu, kultūrinèmis ir kt. charakteristikomis. Kolektyvinio identiteto (tapatumo) sąvoka vartojama šalia (ar vietoje) labiau paplitusių etninio / nacionalinio / tautinio bei kultūrinio ir religinio identiteto (tapatumo) sąvokų ir jas apima. Atitinkamai sinonimiškomis laikomos tautos ir nacijos, tautinio tapatumo (identiteto) ir nacionalinio tapatumo (identiteto) sąvokos.

Bulgarų ir lietuvių kolektyvinio tapatumo pobūdis, be abejo, ne kartą yra sulaukęs tyrèjų dėmesio, tačiau bendras bulgarų ir lietuvių tapatumas niekada nebuvo lygintas tarpusavyje (5). Šis darbas išsiskiria tuo, kad tyrime pirmą kartą lyginamas bulgarų ir lietuvių kolektyvinis tapatumas, tapatumo konstravimo aplinkybès, jo raiška.

(3) 2010 m. „The World Factbook“ duomenys (prieiga per inernetą: https://www.cia.gov/index.html).

(4) Ortodoksinè bulgarų religija buvo pagrindinis veiksnys, formuojantis tautinị bulgarų identitetą ir atskiriantis juos nuo turkų (musulmonų). Slaviška Kirilo ir Metodijaus abėcèle, pritaikyta krikščioniškoje bažnyčioje, skyrè slavų kalba kalbančius bulgarus nuo ortodoksų graikų. XIX a. Bulgarijoje kilusios stiprios panslavistinès idejos pabrèžè bulgarų slaviškumą, jų artimumą kitiems slavams - taigi skatino priešintis Osmanų valdymui. Bulgarijai išsivadavus iš turkų ịtakos, o regione sustiprèjus kitų slavų, serbų ir rusų, ịtakai, šios idejjos susvyravo. XX a. antrojoje pusèje Sovietų Rusijai įtraukus Bulgariją ị savo įtakos zoną, toliau oficialiai buvo itin pabrěžiama slaviška bulgarų kilmè. Ir nors bulgarai buvo dẻkingi rusams už jų pagalbą atgaunant Bulgarijos nepriklausomybę XIX a. pabaigoje, sovietiniu laikotarpiu, ieškant bulgarų tautinio unikalumo, atsigręžta ị senąją istoriją, bulgarų kilmė dažnai sieta su senaisiais trakais arba (dar dažniau) su protobulgarais, tiurkų gentimi, ịkūrusia pirmą Bulgarijos valstybę.

(5) Išimtị sudaro tik tam tikri atskirų bulgarų ir lietuvių kultūrų elementų palyginimai, kuriuos sąlyginai galima susieti ir su tapatumo palyginimais (žr. Balkan and Baltic States in United Europe: Histories, Religions, and Cultures. Sofia: Paradigma, 2010 ir kt.). Būta ir bandymų gretinti bulgarų ir lietuvių etnogenezę. Pasitelkdamas folkloro ir etnokultūrinius duomenis šią teoriją XX a. pradžioje įrodinèjo Jonas Basanavičius [1] ir kt. 


\section{TYRIMO APIBŪDINIMAS}

Konstruojant žvalgomojo tyrimo klausimyną, stengtasi apimti svarbiausius tautinị, religini ir kultūrinị identitetą nusakančius indikatorius (atsižvelgiant ị literatūroje pateiktus šių šalių gyventojų kolektyvinio identiteto konstravimo elementus). Pasitelkus žvalgomąji pusiau struktūruotą klausimyną (anglų kalba), sudarytą iš 10 prasminių klausimų blokų (klasterių), bandyta apžvelgti dabartinį Bulgarijos akademinio jaunimo identitetą, pagrindinius jo kaitos ypatumus (6).

Be abejo, kyla nemažai sunkumų, kai apie tapatumą reikia spręsti iš žmonių nuomonių, nes jas lemia daugelis veiksnių. Nesiremta tradicine sociologine apklausa, kuri lengviausiai (tačiau ir mažiausiai patikimai) padètų sužinoti kolektyvinès sąmonès parametrus. Pasirinktas kokybinis tyrimo būdas leidžia nuodugniau sužinoti respondentų motyvaciją, argumentaciją tam tikrais klausimais, pateikia tyrèjui išsamesnį analizuojamo klausimo vaizdą.

Dauguma pateiktų klausimų buvo atviri, prie kai kurių buvo išvardyti galimų atsakymų variantai. Drauge (visų pirma nagrinejjant realų respondentų religingumą) buvo įtrauktas ir psichometrinis tyrimas, kurio rezultatai leidžia „išskleisti“ socialinę elgseną ir gauti dar tikslesnị respondento nuomonės vaizdą. Šios metodologijos reikšmè itin svarbi tada, kai respondento abstraktūs teiginiai / atsakymai nesutampa su jo realios elgsenos modeliais. Pavyzdžiui, nurodęs, kad yra krikščionis, psichometrinio tyrimo metu atskleidžiama, kad realybėje respondentas nesivadovauja krikščioniško elgesio principais.

Pirmas klausimų blokas buvo skirtas bendriausiai su respondentais susijusiai informacijai gauti (buvo prašoma nurodyti gimimo metus, lytị, užsièmimą, tačiau neprašyta pateikti išsamesnès asmeninès informacijos). Tolesnès klausimyno dalys sukonstruotos taip, kad apimtų populiariausius kolektyvinio bulgarų identiteto elementus.

Antroje klausimyno dalyje studentų buvo prašoma atsakyti, ar jie yra bulgarai, ir paaiškinti savo teiginị; taip pat prašyta nurodyti gimtąją kalbą ir etninę kilmę. Trečioje klausimyno dalyje domètasi bulgarų etniniu išskirtinumu: kas išskiria bulgarus iš kitų tautų, kokie bruožai yra būdingi bulgarams, kokie yra išskirtiniai bulgarų kultūros ypatumai, kas laikytina Bulgarijos simboliu. Panašaus tikslo siekta ir septintu klausimų bloku: studentų klausta apie populiariausias bulgarų šventes, tradicinès bulgarų kultūros (folkloro) ypatumus bei svarbiausius šalies istorinius įvykius. Su kultūriniu bulgarų tapatumu sietinas ir devintas klausimyno blokas, kuris buvo skirtas išsiaiškinti, kokias bendras bulgarams šventes dažniausiai švenčia studentai (7).

Šeštu klausimyno bloku siekta išsiaiškinti bulgarų studentų požiūrị i k kitas tautas, daugiausia dėmesio skiriant jų artimiausiems kaimynams (turkams, graikams, rumunams, serbams, makedonams) bei vienai gausiausių Bulgarijos etninių mažumų - čigonams (8). Tokie klausimai ị klausimyną buvo ịtraukti remiantis prielaida, kad etninis tapatumas labai priklauso nuo kolektyvinio skirtumo tarp „mes“ (šiuo atveju - bulgarų) ir „kiti“ (šiuo atveju - ne bulgarų). Specialiai domètasi ir bulgarų studentų požiūriu ị rusus (są-

(6) Tiriant bulgarų kolektyvinị identitetą, Bulgarijoje buvo atlikti ir keturi išsamūs interviu su gerai informuotais pateikèjais, bulgarų kultūros specialistais, kurie padèjo geriau suprasti tam tikrus bulgarų etninio, kultūrinio bei religinio identiteto ypatumus.

(7) Švenčių sąrašas buvo sudarytas pagal internete pateiktas populiariausias bulgarų šventes.

(8) Bulgarų identitetui labai svarbus lyginimasis su čigonais [8, 93]. Žodžiai ir frazès „čigoniškas“, „čigono darbas“ reiškia „blogai padaryti, sujaukti, sugadinti“. Masių sąmoneje čigonai nesuvokiami kaip reali mažuma, kaip kad kitos etninès bendruomenès šalyje, jie laikomi kitokiais, žemesniais, prastesniais, nevisaverčiais, kurie negali prilygti daugumai $[9,20]$. 
lygotu bulgarų ir rusų tarpusavio kontaktų, susiklosčiusių dẻl specifinių istorinių sąlygų) bei lietuvius (dèl atliekamo bendro lyginamojo bulgarų ir lietuvių kolektyvinio tapatumo tyrimo specifikos). Specifinėms bulgarų žinioms apie lietuvių kultūrą išsiaiškinti buvo skirtas ir aštuntas klausimų blokas: domètasi, ką bulgarų studentai laiko būdingiausiais lietuvių kultūros dalykais, ar žino, kokia religija vyrauja Lietuvoje.

Ketvirta, penkta bei dešimta klausimyno dalys buvo skirtos išsiaiškinti bulgarų studentų požiūrị i krikščionybès santykị su bulgarų etniniu identitetu bei analizuoti bendrą jų religingumą. Šie klausimai ị klausimyną įtraukti todèl, kad, kaip minèta, religijos vaidmuo kolektyvinio identiteto formavimosi procesuose Balkanuose buvo gal net svarbesnis nei kalba ar etninè kilmè: tautinių valstybių sukūrimas, pradedant XIX a. pradžia, Balkanuose visų pirma buvo bandymai atkurti ikiosmaniškas krikščioniškas valstybes. Religinio tapatumo samprata tyrime grindžiama bendrąja tapatumo koncepcija, akcentuojančia emocinị individo tapatinimąsi su konkrečiu objektu (šiuo atveju religija). Skiriami du religinio tapatumo lygmenys - formalusis (išorinis) ir realusis (vidinis). Klausimyne domètasi tiek formaliais, tiek realiais bulgarų studentų religingumo rodikliais.

Ketvirtu klausimų bloku siekta išsiaiškinti formalų studentų religingumą: prašyta nurodyti savo konfesinę priklausomybę, klausta, ar tikras bulgaras turi būti krikščionis ortodoksas, domėtasi, kiek svarbi religija respondentu gyvenime, kokiomis progomis jie eina ị cerkvę. Penkta klausimyno dalis turejo atskleisti respondentų vidinio religingumo laipsnị. Tiriant realų religingumą i autorès klausimyną kaip sudedamoji dalis buvo ịtrauktas psichometrinis Duke’o universiteto religijos indekso klausimynas (DUREL), sudarytas iš penkių religingumą vertinančių kriterijų. Tam tikras vidines studentų nuostatas religijos atžvilgiu turejjo atskleisti ir devinta klausimyno dalis (susijusi su šventėmis), kurioje prašoma nurodyti, kokių švenčių metu respondentai lankosi cerkvėse, ir dešimta klausimyno dalis, kurioje domètasi studentų tikejimu tam tikrais fenomenais (pvz., pomirtiniu gyvenimu) bei jų nuostatomis tam tikrų dalykų, vienaip ar kitaip susijusių su religija, atžvilgiu (pvz., požiūriu ị eutanaziją, abortus ir kt.).

Naudojant parengtą klausimyną, 2010 m. spalio mėnesį Bulgarijos Sofijos ir Plovdivo universitetuose buvo apklausta po 50 pirmo kurso studentų. Šie studentai pasirinkti siekiant, kad jų atsakymus mažiau paveiktų studijų metu igaunamos žinios.

Rezultatų apžvalgai atsirinkti 86 klausimynai. Tiesa, pažymėtina, kad ne visi studentai atsake ị visus klausimynuose buvusius klausimus. Nepaisant to, analizuojant studentų atsakymus, nagrinejjami visi (pilnai ir nepilnai atsakyti) klausimynai. Be abejo, tai gali sąlygoti tam tikrą procentinès išraiškos paklaidą (procentai skaičiuoti nuo 86 anketų, bet ne nuo konkretų klausimą vienaip ar kitaip atsakiusių studentų skaičiaus), tačiau darbo autore ir nesieke išsiaiškinti tikslių procentų, o domejjosi iš atsakymų ryškejjančiomis bendromis kolektyvinio identiteto konstravimo tendencijomis, analizavo, kaip žvalgomojo tyrimo rezultatus būtų galima panaudoti konstruojant išsamesnị būsimą bulgarų kolektyvinio identiteto tyrimą.

Beje, reikia atkreipti demesị i tai, kad klausimai respondentams buvo pateikti anglų kalba, todèl bulgarų studentams dèl kalbos barjero galejo būti problemiška atsakyti ị tam tikrus klausimus.

Norint palyginti bulgarų ir lietuvių studentų kolektyvinio identiteto ypatumus, atitinkamas klausimynas (taip pat anglų kalba) buvo pateiktas ir 50-iai lietuvių studentų (taip pat pirmakursiams), studijuojantiems Kaune. Tiesa, klausimynas buvo pertvarkytas taip, kad atitinkamais klausimais buvo klausiama ne apie bulgarų, bet apie lietuvių kultūrą, religiją, 
Šventes, požiūrị i kaimynines tautas ir pan. Klausimai bulgarų studentams apie lietuvius ir lietuvių kultūrą lietuvių studentams buvo performuoti ị klausimus apie bulgarus ir bulgarų kultūrą.

Tyrimo rezultatai darbe pateikiami procentais arba tiesiog nurodomos bendros išryškejjusios tendencijos. Be abejo, atliktas nedidelis žvalgomasis tyrimas toli gražu nereprezentuoja visų bulgarų ar lietuvių kolektyvinio identiteto konstravimo ypatumų, neleidžia daryti apibendrinančių išvadų, tačiau padeda įžvelgti tam tikrus identiteto konstravimo ir kaitos procesus. Tikimasi, kad šis žvalgomasis tyrimas padès parengti tobulesnị, kokybiškesnị klausimyną, atskleidžiantị socialinę elgseną ir papildytą tinkamais indikatoriais.

\section{TYRIMO REZULTATŲ APŽVALGA}

Žvalgomojo tyrimo metu buvo apklausta 100 bulgarų studentų, gimusių 1985-1992 metais (didžioji dalis - 1991 m.), iš jų 63 \% merginų, 37 \% vaikinų. Visi apklaustieji identifikavo save kaip bulgarus, bulgarų kalbą nurode kaip gimtąją kalbą, abu tėvus - esant bulgarų kilmès (9). Kaip minèta, buvo apklausta 50 lietuvių studentų, gimusių 1988-1992 m. (dauguma taip pat 1991 m.), iš jų 50 \% merginų, 50 \% vaikinų. Visi jie įvardijo save kaip lietuvius, lietuvių kalbą nurodè kaip gimtąją kalbą, abu tèvus taip pat teigè esant lietuviais (10).

Savo identifikaciją su bulgarais bulgarų studentai pirmiausia grindė tuo, kad jie gimè ir gyvena Bulgarijoje (31\%), kad jų tèvai bulgarai (17\%), kad jie kalba bulgarų kalba (16 \%), išpažista bulgarų ortodoksų religiją (12\%). Tokius pačius dalykus (tiesa, visų pirma kalbą) nurodè ir aiškindami, kuo bulgarai skiriasi nuo kitų tautų atstovų. Kaip pagrindines bulgarų ypatybes įvardijo svetingumą, mielumą ir gražią išvaizdą, ne vienas respondentas taip pat minèjo draugiškumą bei aistringumą (11).

Savo identifikaciją lietuvių studentai grindè tuo, kad gimė ir gyvena Lietuvoje (44\%), kalba lietuvių kalba (18\%), jų tèvai - lietuviai (18\%), užaugo lietuviškų tradicijų aplinkoje (10\%). Aiškindami, kaip atskirti lietuvius nuo kitų tautų atstovų, lietuvių studentai dažniausiai minèjo lietuvių kalbą (34 \%), nurodè ir meilę krepšiniui (6 \%), XX a. tapusią svarbia lietuvių kolektyvinio tapatumo dalimi. Būdingiausiomis lietuvių autoportreto savybėmis studentai nurodè drovumą (14\%), darbštumą (10\%), draugiškumą (6 \%) ir grožị (6\%) (12).

Taigi pagrindinis požymis, nulèmęs tiek bulgarų, tiek lietuvių tautinị tapatumą, yra jų gyvenamoji šalis. Labai svarbus kriterijus yra ir tèvų etninė priklausomybẻ bei gimtoji

(9) Išskyrus vieną respondentą, kuris nurodė, kad yra bulgaras, jo gimtoji kalba bulgarų, tačiau iš tèvų tik vienas yra bulgaras.

(10) Analogiškas buvo ir vieno lietuvio studento atvejis.

(11) M. Elchinovos $(5,47)$ rezultatų duomenimis, studentai apibūdino bulgarus kaip labai išsilavinusius, temperamentingus, besimėgaujančius gyvenimu, ambicingus, tačiau materialius, savimylas, nepunktualius.

(12) Pažymėtina, kad šio tyrimo rezultatai ženkliai skiriasi nuo atitinkamų ankstesnių tyrimų rezultatų, autorès atliktų tarp lietuvių studentų 2001-2002 bei 2005 metais [11, 12]. Anksčiau respondentai dažniausiai minėdavo lietuvių pavydumą, uždarumą ir darbštumą. Tokius respondentų atsakymų pokyčius galima interpretuoti ịvairiai. Gali būti, kad lietuvių autoportretas tarp akademinio jaunimo palaipsniui gereja. Kitas galimas aiškinimas gali būti ir toks, kad šio tyrimo metu studentai nujautė, kad jų rezultatai gali būti lyginami su kitų kraštų studentų rezultatais, todèl (gal ir nesąmoningai) norejo pateikti pozityvesnị savo tautiečių vaizdinị. 
kalba. Pagrindinis skirtumas tarp bulgarų ir lietuvių atsakymų, aiškinant identifikaciją su sava tauta, yra tas, kad bulgarų studentų tautiniam tapatumui suvokti svarbi religinè identifikacija, kai tuo tarpu lietuviai studentai nesieja religijos su savo tautiniu tapatumu.

Nurodydami ypatingus bulgarų kultūros bruožus bulgarų studentai teigè, kad juos geriausiai atskleidžia tradicinis maistas ir gèrimai (visų pirma išskyrẻ rakiją, taip pat kisielių (13)). Kaip specifinius folkloro dalykus minėjo liaudies muziką ir dainas (24\%), šokius (22\%) bei tradicinę aprangą (6\%). Išskirtiniais lietuvių kultūros bruožais lietuvių studentai ịvardijo lietuvių liaudies dainas (visų pirma raudas, karo, darbo dainas - $22 \%$ ), šokius (12\%), liaudies pasakas (8\%) bei tradicinę aprangą (6\%). Ypatingu lietuvių kultūros bruožu lietuvių studentai nurodè ir meilę krepšiniui (8\%) (14). Taigi tiek bulgarams, tiek lietuviams savos kultūros specifika visų pirma asocijuojasi su tradicinès kultūros atributais. Specifinè čia yra lietuvių nuostata krepšinio atžvilgiu.

Kaip pagrindinị Bulgarijos simbolị daugiausia bulgarų studentų minejjo liūtą (15). Antroje vietoje pagal paminèjimo dažnumą Bulgarijos simboliu buvo rožè / rožès (16), trečioje - Bulgarijos vẻliava. Pagrindiniu Lietuvos simboliu lietuvių studentai teigè esant Lietuvos vèliavą (38 \%), Vytị (21\%) bei krepšinị (8 \%). Šiuo atveju vyrauja šalį reprezentuojantys valstybingumo simboliai. Išimtis būtų Bulgarijos siejimas su rožèmis, o Lietuvos (ir vèl) - su krepšiniu.

Svarbiausiu Bulgarijos istoriniu ịvykiu bulgarų studentai laiko Bulgarijos išsivadavimą iš turkų 1878 m. (26\%). Nemaža dalis akcentuoja 681 metus - pirmos Bulgarijos valstybès susidarymą (15\%) ar Bulgarijos suvienijimą (14 \%) (17). Svarbiausiu Lietuvos istoriniu ìvykiu Lietuvos studentai laiko $1990 \mathrm{~m}$. kovo $11 \mathrm{~d}$. - Lietuvos nepriklausomybès atkūrimo dieną (31 \%) arba $1918 \mathrm{~m}$. vasario $16 \mathrm{~d}$. - Lietuvos valstybès atkūrimo dieną (25\%). Tiesa, didele dalis respondentų kaip svarbiausią Lietuvos istorinị ịvykị nurodė Žalgirio mūši 1410 m. (25\%) (18).

Atsakydami ị klausimą apie savo religinę priklausomybę didesnė dalis bulgarų studentų teigè esantys krikščionys (priklausantys Bulgarijos ortodoksų bažnyčiai). Tiesa, jie pripažino, kad yra pernelyg nepraktikuojantys, cerkvėse apsilankantys tik per didžiąsias metines religines šventes. Tik $9 \%$ bulgarų respondentų save ịvardijo kaip apskritai nereligingus, o du respondentai teigè esantys musulmonai. Tai, kad religija Bulgarijoje formaliai populiari, rodo ir atsakymai ị klausimą, ar tikras bulgaras turi būti krikščionis ortodoksas; net $67 \%$ respondentų ị šị klausimą atsakè teigiamai.

(13) Taip bulgarai vadina specifinị jogurtą (Kiselo Mlyako).

(14) Tą patị respondentai teigè $2005 \mathrm{~m}$. atliktos apklausos metu [12, 128].

(15) Liūtas yra susijęs su Bulgarijos herbu. Raudoname herbo skyde vaizduojamas ant užpakalinių kojų stovintis liūtas su istorine Bulgarijos karūna; skydą taip pat prilaiko du liūtai.

(16) Bulgarija pirmauja pasaulyje pagal rožių aliejaus gamybą. Rožių slènis, esantis prie Kazanlyko miesto, - vienas stambiausių rožiu aliejaus gamintojų pasaulyje.

(17) Pasak, E. Krastevos-Blagoevos [8, 92], istorinès žinios suvokiamos kaip esminis elementas formuojantis Bulgarijos nacionaliniam identitetui. Ši nacija nę̨sivaizduojama be bendros nacionalinès atminties ir bendrų protėvių suvokimo. Bulgarijos istorija suvokiama kaip itin sena ir ji suprantama kaip labiausiai prestižinis tautos atributas [4, 237].

(18) Čia taip pat atsispindi senosios Lietuvos idealizacija: Žalgirio mūšis - tarsi simbolinè paskutinių pagonių kova su kryžiuočiais - krikščionybès platintojais. Kita vertus, respondentų dažną Žalgirio mūšio akcentavimą galèjo sąlygoti ir tai, kad apklausos atlikimo metais plačiai buvo minimas mūšio 600 metų jubiliejus. 
Katalikais save laiko $83 \%$ procentai lietuvių respondentų, nereligingais - $13 \%$. Vienas respondentas teigė esąs pagonis, dar vienas - politeistas. Tiesa, $60 \%$ lietuvių studentų mano, kad religija nèra svarbi jų gyvenime. It bažnyčią, respondentų teigimu, jie dažniausiai eina tik per didžiąsias krikščionių šventes - Kalèdas ir Velykas. Beje, 58 \% lietuvių mano, kad tikras lietuvis turi būti katalikas. Taigi bet kuriuo atveju mažesnẻ lietuvių respondentų dalis (palyginti su bulgarais) mano, kad religija yra svarbi lietuvių kolektyviniam tapatumui.

Bulgarų studentų taip pat klausta, ar dažnai jie lankosi cerkvẻje. Pusė apklaustųjų atsakė, kad kelis kartus per metus, per didžiąsias krikščionių šventes. Tik kelis kartus buvę cerkvejje nurodè $14 \%$ apklaustųjų, niekada - taip pat $14 \%$ respondentų. Kelis kartus per mènesị $\mathfrak{i}$ cerkvę teigè einantys $20 \%$ respondentų. Asmeniškai meldžiasi dar mažesnis kiekis jaunų bulgarų, niekada to nedarantys teigè netgi $71 \%$ respondentų. Tik trys bulgarų respondentai teigè, kad meldžiasi kasdien.

Lietuvių studentų taip pat buvo teirautasi, ar dažnai jie lankosi bažnyčioje. Dauguma jų teigè, kad kelis kartus ar kartą per metus, per didžiąsias krikščioniškas šventes (62 \%). Asmeniškai niekada nesimeldžia taip pat dauguma lietuvių studentų (net 76\%), kasdien meldžiasi tik $4 \%$.

Atsakydami ị klausimyno dalį, parengtą pagal DUREL klausimyną ir skirtą ištirti vidiniam religingumui, studentai pademonstravo labai skirtingus požiūrius.

Dievo buvimą kasdieniame gyvenime jaučia $22 \%$ apklaustų bulgarų, dar $16 \%$ nèra tuo visai tikri, 14 \% teigè, kad tikrai nejaučia. Priešingai, dauguma lietuvių nebuvo tikri, kad jie jaučia Dievo buvimą apskritai.

Atsakydami ị klausimą, ar religiniai ịsitikinimai veikia jų gyvenimą, studentai bulgarai labai tuo abejojo: jų nuomonès smarkiai ir daugmaž tolygiai išsiskyrè tarp „taip, labai veikia“ ir „ne, visai neveikia“. Skirtingus atsakymus pateike ir lietuviai.

I klausimą, ar stengiasi įtraukti religiją ị savo gyvenimą, respondentai pateikè labai skirtingus atsakymus, tačiau didesnè bulgarų (44\%) ir lietuvių dalis (50 \%) teigè, kad to tikrai nedaro.

Abejones religinėmis krikščionybès dogmomis rodo ir studentų bulgarų atsakymai i klausimus, ar jie tiki reinkarnacija, pomirtiniu gyvenimu, trejybe, telepatija, rojumi, Dievu kaip asmeniu, pirmine nuodème. Atsakymai „taip“ ir „ne“ daugiausia pasiskirste tolygiai, išskyrus vyraujančią tarp bulgarų tendenciją netikèti Trejybe bei Dievu kaip asmeniu. Lietuvių studentai linkę labiau netikèti reinkarnacija, rojumi, Dievu kaip asmeniu ir labiau tikèti pomirtiniu gyvenimu bei telepatija.

Religines pažiūras sąlyginai turèjo atskleisti ir tam tikrų dalykų vertinimas. Teirautasi bulgarų studentų nuomonès dèl eutanazijos, abortų, skyrybų, savižudybių, kohabitacijos, nebažnytinès santuokos, gyvenimo be krikšto, laidojimo be bažnytinių apeigų. Iš minètų dalykų bulgarų studentai negatyviai vertina tik savižudybę. Labiau negatyviai nei pozityviai jie linkę vertinti ir abortus, tačiau požiūris į nebažnytinę santuoką bei skyrybas labai pozityvus. Kitais klausimais studentų nuomonè smarkiai skyrèsi.

Lietuviai minètus dalykus vertina neutraliai, negatyviau vertina tik savižudybę (52\% apklaustųjų).

Nurodydami tautas, su kuriomis bulgarų kultūra turi daugiausia bendrumų, bulgarų respondentai dažniausiai minèjo makedonus (49\%) (beje, reikia turèti omenyje, kad ne- 
mažai bulgarų makedonų apskritai nelaiko atskira tauta, tik bulgarais - tą pabrèžè dažnas respondentas (19)), serbus (47\%) bei rusus (45\%).

Studentams taip pat reikèjo įvardyti, kiek bulgarai yra panašūs i graikus, turkus, rumunus, čigonus ir lietuvius. $20 \%$ bulgarų studentų teigè, kad yra panašūs ì graikus ar bent iš dalies panašūs (30\%), $16 \%$ - kad yra panašūs ì rumunus ar iš dalies panašūs (30\%), tik $5 \%$ teigè, kad yra panašūs ị turkus ar iš dalies panašūs (21\%) (20). Bulgarų panašumą i čigonus pripažino tik du respondentai, $13 \%$ mano, kad iš dalies panašūs, $28 \%$ - visai nepanašūs.

Apibūdindami savo kaimynus bulgarai griežčiausi buvo turkams, dažniausiai teigdami, kad turkai yra kvaili, bjaurūs žmonès. Panašiai kalbejjo ir apie graikus. Daug geriau atsiliepė apie kitus kaimynus - serbus ir rumunus. Serbus įvardijo kaip „vakarèlių žmones“, mègstančius ir mokančius pasilinksminti, rumunus - kaip laimingus žmones. Vieną didžiausių etninių mažumų - čigonus - respondentai dažniausiai buvo linkę apibūdinti kaip nešvarius žmones. Domètasi ir bulgarų požiūriu ị rusus. Pasak respondentų, rusai yra tradicijų besilaikantys geri žmonès (21).

Lietuviai dažniausiai nurodè savo kultūros panašumus su latviais (75\%), lenkais (60 \%) ir estais (38 \%), taip pat rusais (31\%). Vertinant kaimynines tautas skaleje nuo „labai panašūs“ iki „visai nepanašūs“ latviai dažniausiai ịvardyti kaip „labai panašūs“ (48 \%) ar „panašūs“ (20\%). Atitinkamas kiekis respondentų (48\%) teigè, kad lietuviai „panašūs“ ị lenkus, $28 \%$ - „labai panašūs“, 44 \% lietuvių studentų teigè, kad lietuviai „panašūs“ į rusus, likusieji atsakymai daugmaž vienodai pasiskirste tarp „visai nepanašūs“ (22\%) ar „labai panašūs“ (18\%).

(19) Kaip rašo N. Daviesas [3, 152], Senoves Makedonijos istorija prasidèjo ilyrų ir trakų civilizacija. Tiesa, didelè jos dalis buvo helenizuota dar prieš Pilypui Makedoniečiui užkariaujant Graikiją. Romos provincija Makedonija driekèsi ligi Adrijos jūros, ir nuo VI a. ją tirštai apgyvendino čia migravę slavai. Viduramžiais Bulgarijos imperijos sudètyje atsidūrusi Makedonija buvo Bulgarijos stačiatikių bažnyčios egzarchato dalimi, tai sustiprino vèlesnes Bulgarijos pretenzijas ị ją. XIV a. Makedonija pateko ị serbų valdžią, paskui - osmanų. Tada plito islamas, o visi stačiatikiai krikščionys buvo laikomi „graikais“, nes buvo pavaldūs Konstantinopolio patriarchui. Per Balkanų karus XX a. pradžioje dèl Makedonijos kovojo Graikija, Bulgarija ir Serbija. Makedonija buvo padalyta ị tris dalis. Pietų Makedonija su centru Tesalonikais atiteko Graikijai, Rytinè Makedonija atsidūrè Bulgarijoje, kuri laikè ją „,vakarine Bulgarija“, o likusi dalis atiteko serbams (1945 m. ši dalis gavo Jugoslavijos autonominès respublikos statusą; čia prasidèjo ryžtinga kampanija supaprastinti Makedonijos istoriją ir pakeisti visų gyventojų identitetą; slaviškas makedonų dialektas buvo paskelbtas atskira kalba, o senoji bažnytinè slavų kalba imta laikyti „senąja makedonų kalba“; jaunimas buvo auklèjamas „slaviškos Makedonijos" tradicijų dvasia).

Dèl minètų priežasčiu makedonus bulgarai laiko bulgarais, kalbančiais bulgarų kalbos dialektu, graikai Makedoniją laiko savo dalimi, o makedonai laikosi savitos etninès savimonès. Identifikacija „makedonas" $1950 \mathrm{~m}$. Bulgarijoje buvo uždrausta.

(20) Bulgarijos kultūra ilgą laiką buvo labai veikiama rytietiškos osmanų kultūros (visų pirma tai veikè gyvenimo būdą, mentalitetą, virtuvę ir kt.) [6, 273]. Kita vertus, jautimasis bulgaru taip pat buvo pagrịstas skirtinga nuo osmanų kultūra ir gyvenimo būdu $[2,109 ; 10]$.

(21) Pažymètina, kad Bulgarijoje, skirtingai nei daugelyje buvusio komunistinio bloko šalių, rusų ir Rusijos įvaizdis palyginti yra labai pozityvus. Juk Bulgarijos šalies atsiradimą daugiausia lèmè Rusijos karas su Turkija. Nemažai žmonių ilgisi tų laikų, kai Sovietų Sąunga rèmè satelitines šalis, tarp jų ir Bulgariją, neretai ignoruodami sovietų darytą žalą Bulgarijos kultūrai. 
Latvius lietuviai ịvardijo kaip draugiškus žmones, panašius ị lietuvius (22), estus apibūdino kaip lètus ir draugiškus žmones (23), lenkai, jų manymu, yra savimylos ir pasipūtę (24), rusai - girtuokliai, bet draugiški žmonès (25), o vokiečiai - protingi, šalti ir draugiški (26). Taigi tarp lietuvių studentų labiausiai teigiamas iš kaimyninių šalių gyventojų yra latvių įvaizdis, o labiausiai neigiamas - lenkų. Tiek bulgarai, tiek ir lietuviai, nepaisant sovietų okupacijos ir vykdyto lietuvių etnocido, sąlyginai jautè tam tikras simpatijas rusams.

Lietuvius ir bulgarus esant iš dalies panašius nurodè tik $19 \%$ bulgarų respondentų, visai nepanašius - $18 \%$, neturẻjo nuomonės $34 \%$. Paprašyti nurodyti nors vieną lietuvių savybę, respondentai dažniausiai atsakydavo, kad nieko apie lietuvius nežino. Pasitaikė atsakymų, kad lietuviai yra laimingi, nuobodūs, šalti europiečiai. Tiesa, 45 \% respondentų žinojo, kad lietuviai yra krikščionys.

Tik 20 \% lietuvių respondentų teigé, kad bulgarai kažkuo panašūs ị lietuvius, net 52 \% lietuvių studentų mano, kad bulgarai ir lietuviai yra visai nepanašūs. Dauguma lietuvių studentų apie bulgarus visai neturejo jokios nuomonès. Bulgarų kultūra lietuviams asocijuojasi tik su skaniu maistu. Tiesa, 42 \% lietuvių studentų nurodè, kad bulgarai yra krikščionys, lygiai tiek pat nežinojo bulgarų religinès priklausomybės. Nemažai respondentų spejjo, kad bulgarai yra musulmonai arba dar kokios kitos religijos atstovai (nei krikščionys, nei musulmonai).

Nurodydami populiariausias bulgarų šventes bulgarų studentai minėjo Kalèdas (15\%), Velykas (14\%) ir Kukeri šventę (17\%) (27). Tiesa, atskirai klausinejjami apie jų švenčiamas šventes pateikè šiek tiek kitokius duomenis. Bene populiariausios ir tikrai švenčiamos yra bulgarų valstybingumui ypač svarbios šventės: Bulgarijos išsilaisvinimo diena (iš turkų valdžios 1878 m. - kovo 3 d.), Bulgarijos nepriklausomybės diena (iš turkų Osmanų imperijos - rugsèjo 22 d.) bei Bulgarijos suvienijimo diena (1885 m. buvo suvienytos dvi turkų administraciniu požiūriu padalytos Bulgarijos dalys - Bulgarija ir Rytų Rumelija (su sostine Plovdivu) - rugsèjo 6 d.) (28). Jas švenčia dauguma respondentų.

Toliau tarp bulgarų studentų populiarios šios šventės: Kalėdų išvakarès (dažniausiai nurodytos atliekamos apeigos - vakarienè su šeima, dovanos, eglutės puošimas), Velykos (dažniausiai nurodytos apeigos - kiaušinių dažymas, jų dovanojimas, mušimas, valgymas), Naujieji metai (dažniausiai nurodytas linksminimasis su draugais), Baba Marta (kovo 1 d., dažniausiai nurodytos apeigos - Martenitsos (29) darymas, jos dovanojimas,

(22) Atitinkamai draugiškais ir panašiais ị lietuvius latviai respondentų buvo apibūdinami ir ankstesniame tyrime [11].

(23) Ankstesniame tyrime dažniau buvo pabrèžiamas estų pasipūtimas bei šaltumas [11].

(24) Panašiai lenkai buvo apibūdinami ir ankstesniame tyrime [11].

(25) Panašiai rusai buvo apibūdinami ir ankstesniame tyrime [11].

(26) Ankstesniame tyrime dažniau buvo kalbama apie vokiečių tvarkingumą, jų nacionalistines pažiūras, darbštumą, šaltumą [11].

(27) Apie šios šventès panašumą ị senąsias lietuvių tradicijas rašè dar Jonas Basanavičius. Šventès metu dèvimas kaukes - kukeri - galima gretinti su lietuvių kaukais [1].

(28) 1878 m. ne visa Bulgarija buvo išlaisvinta iš Osmanų imperijos. Rytų Rumelija (su sostine Plovdivu) Berlyno kongreso nutarimu buvo palikta valdyti sultono kalifatui. Trakija ir Makedonija liko priklausomos Osmanų imperijai. Rytų Rumelija galutinai prijungta prie Bulgarijos $1885 \mathrm{~m}$.

(29) Martenitsa - tai nedideli papuošalai iš baltos ir raudonos spalvos vilnonių siūlų: simbolinès lèlytès Pižo (simbolizuojanti vyrišką pradą, baltos spalvos) ir Penda (simbolizuojanti moterišką pradą, raudonos spalvos). Šventè susijusi su artėjančiu pavasariu, išpopuliarinta formuojant modernų, nacionalinị bulgarų unikalumą. 
nešiojimas), Jurginès (Gergyovden, gegužès 6 d.; dažniausiai nurodytas ritualas - èriuko kepimas, taip pat gausus valgymas), Šv. Mikalojaus diena (Niculden, gruodžio 6 d.; dažniausiai nurodytas ritualas - žuvies kepimas), Šv. Kirilo ir Metodijaus diena (gegužès 24 d., respondentai teigè, kad ši šventè buvo privaloma mokyklose) (30). Nors studentai Kukeri šventę minėjo tarp populiariausių šalies švenčių, realiai ją švenčia tik maždaug trečdalis bulgarų respondentų.

I cerkvę dažniausiai Bulgarijoje einama tik per Velykas (maždaug pusė respondentų) ir Jurgines (maždaug trečdalis respondentų). Švenčiantys Verbų sekmadienį (maždaug trečdalis visų respondentų) tą dieną taip pat eina ị cerkvę. Per Kalèdas bažnyčioje apsilanko tik maždaug šeštadalis visų bulgarų respondentų.

Populiariausiomis lietuvių šventèmis lietuviai studentai nurodė Kalèdas (58 \%), Velykas (42\%), Jonines (31 \%) ir Naujuosius metus (23 \%). Žymėdami pateiktame sąraše savo švenčiamas šventes studentai lietuviai nurodè, kad populiariausios yra Kūčios, Kalèdos (94%; kaip pagrindinį ritualą nurodė Kūčių vakarienę su šeima, eglutės puošimą, per Kalèdas - dovanèles), Naujųjų metų sutiktuvès (94\%; pagrindinè veikla - vakarèliai su draugais), Velykos (90 \%; pagrindinis akcentas - dažyti kiaušiniai), Motinos diena (90 \%; sveikinamos mamos, joms dažniausiai dovanojamos gèlès), Vèlinès ( $83 \%$; pagrindinis ritualas - kapų lankymas), Tẻvo diena (69 \%; sveikinami tèvai), Joninès (58 \%; linksminamasi gamtoje, kūrenami laužai).

Valstybinès šventès lietuviams kur kas mažiau svarbios nei bulgarų studentams. Iš valstybinių dienų studentams svarbiausia yra Lietuvos nepriklausomybès atkūrimo diena - kovo 11-oji, mažiausiai reikšminga - Valstybės diena (liepos 6 d.). I bažnyčią Lietuvoje dažniausiai einama per Velykas (64\%), Kūčių vakarą (50 \%) arba per Kalèdas $(46 \%)$.

\section{IŠVADOS}

Atliktas žvalgomasis tyrimas (31) leidžia preliminariai teigti, kad sąlyginai panašios istorinès aplinkybės Bulgarijoje ir Lietuvoje formuoja ir panašius kolektyvinị identitetą lemiančius veiksnius. Tiek bulgarai, tiek lietuviai didelę reikšmę teikia savo tautos gyvenamai teritorijai, kalbai, kilmei.

Tyrimo metu išaiškejo ir kai kurie bulgarų bei lietuvių kolektyvinio identiteto skirtumai:

- Religinis identitetas kaip sudedamoji tautinio tapatumo dalis net ir šių laikų kolektyviniam bulgarų tapatumui yra daug svarbesnis negu lietuvių kolektyviniam tapatumui. Nepaisant to, tiek bulgarų, tiek lietuvių tikras religingumas nėra didelis. Apklausa rodo, kad lietuvių studentai dar mažiau religingi negu bulgarų studentai.

- Istorinè atmintis daro labai didelị poveikị tiek vienos, tiek kitos šalies respondentų tapatumui, tačiau Bulgarijoje daug labiau domimasi savo istorija ir iš tikrųjų švenčiamos šalies valstybingumui svarbios dienos. Svarbiausiais istoriniais įvykiais abiejų šalių studentai laiko datas, susijusias su šalies valstybingumu.

(30) Ši diena švenčiama ir kaip Bulgarijos abėcèlès ir kultūros diena. Šventieji broliai Kirilas (Konstantinas) ir Metodijus yra žinomi kaip slaviškos abėcèlès autoriai. Kirilas sukūrè senąjị bažnytinị slavišką raštą - glagolicą, vèliau - kiriliką, kuri iki šiol vartojama Rusijoje, Bulgarijoje, Serbijoje, Baltarusijoje, Ukrainoje, taip pat rusų ir graikų stačiatikių bažnyčiose.

(31) Tyrimas atliktas pagal dvišalę sutartị tarp Lietuvos ir Bulgarijos mokslų akademijų. Tyrimą finansavo Lietuvos mokslo taryba (sutarties Nr. KEL-187/2010). 
- Nors tradiciniais skiriamaisiais kultūros bruožais tiek lietuviai, tiek bulgarai laiko tradicinès kultūros dalykus, kalbą, gana nemaža reikšmė lietuvių kolektyviniame identitete teikiama krepšiniui.

- Tiek bulgarai, tiek lietuviai suvokia savo panašumus su jiems gretimo regiono kultūromis, jų atstovais. Tiesa, lietuviai daug palankiau apibūdina kaimyninių šalių gyventojus nei bulgarai. Bulgarai itin nepalankiai žiūri ị tautas, su kuriomis kažkada (iš dalies ir dabar) konfliktavo (ị graikus ir ypač turkus). Šiuo požiūriu lietuviai kaimyninèms tautoms daug atlaidesni.

- $\quad$ Nors tiek Bulgarija, tiek Lietuva yra Europos Sajungos valstybès, atliktas tyrimas rodo, kad nei lietuvių, nei bulgarų studentai vieni apie kitų kultūrą praktiškai nieko nežino.

Gauta 20111121

Priimta 20111228

\section{Literatūra}

[1] BASANAVIČIUS, Jonas. Trakų ir lietuvių mitologijos studijos. Rinktiniai raštai. Vilnius: Vaga, 1970, p. 358-391.

[2] DASKALOV, Rumen. Meždu Iztoka i Zapada. Balgarski kulturni dilemi. Sofia: Lik., 1998.

[3] DAVIES, Norman. Europos istorija. Vilnius: Vaga, 2008.

[4] DITCHEV, Ivaylo. The Eros of Identity. Balkan as Metaphor. Between Globalization and Fragmentaition. Cambridge, Mass: MIT Press, 2002, p. 235-251.

[5] ELCHINOVA, Magdalena. Bulgaria’s Way to Europe: Some Aspects of Identity Construction among Bulgarians Studnts today. Ethnologia Balkanica, 2004, vol. 8, p. 35-55.

[6] GENČEV, Nikolaj. Balgarskata kultura XV-XIX v. Sofia: Sofia University, 1988.

[7] KOENING, Harold G.; MEADOR, Keith G.; PARKERSON, Georg R. Religion Index for Psychiatric Research: A 5-item measure for Use in Health Outcome Studies. American Journal of Psychiatry, 1997, vol. 154, p. 885-886.

[8] KRASTEVA-BLAGOEVA, Evgenija. Who Are We? Types of Collective Identities in Contemporary Bulgaria. Etnologia Balkanica, 2003, vol. 7, p. 89-105.

[9] POPOV, Vesselin. Bulgarian Gypsies. The Ethnic Situation in Bulgaria. Sofia: Club'90 Publishers, 1993, p. 17-26.

[10] ROTH, Klaus. Coming to Terms with the Past? The Ottoman Legacy in Southeast Europe. Mediterranean Ethnologial Summer School, 1999, vol. 3, p. 219-235.

[11] SENVAITYTÉ, Dalia. Lietuvių etniniai stereotipai: tautybès studentų akimis. Tiltai, 2004, Nr. 4, p. 123-129.

[12] SENVAITYTĖ, Dalia. Etninès kultūros tradiciju tęstinumas ir iššūkiai šiuolaikinejje visuomenèje. Klaipeda, 2009, p. 123-130. 
DALIA SENVAITYTÉ

\section{Traits of collective identity of Bulgarians and Lithuanians: comparative analysis of students' standpoint}

Summary

The essential reasons that determined specific particularities of the collective Bulgarian and Lithuanian identity are reflected also in the national identity of contemporary Bulgarian and Lithuanian students.

Data of a comparative pilot qualitative research (concentrated on the collective identity) carried out among Bulgarian and Lithuanian students in 2010 show some substantial similarities of constructing collective identities and their actual expressions. The same Bulgarians and Lithuanians stress the importance of their homeland, language and ethnic origin to their national identities. However, some significant differences were also observed.

The main distinction is the place of religion in the construction of national identities of modern students. Religion is a very important factor in national identity construction for contemporary Bulgarians and is practically insignificant for Lithuanians. Nevertheless, real religiosity is intense neither in Bulgaria nor in Lithuania. Religion in Bulgaria is first of all understood as an important element of collective identity.

The results of the research also show that, despite the importance of common national history in the national identity construction processes in Bulgaria and Lithuania, Lithuanian students actually give less importance to the country's main historical events as compared with Bulgarian students. The majority of Bulgarians students actually commemorate their historical events (national days), whereas only the minority of Lithuanian students do so.

Both Bulgarians and Lithuanians believe that their language and folk culture elements represent their culture best; also, Lithuanians strongly amplify the role of basketball in their collective Lithuanian identity.

Bulgarian and Lithuanian students perceive the similarity of their culture to the culture of their neighbouring countries. However, Lithuanian students as compared with their Bulgarian matches rank all their neighbours much more positively regardless of the historical relations with them. Bulgarians' stereotypes concerning Turks and Greeks are very negative.

The data of the research have also shown that, although both countries are in Europe and have historical parallels, both Bulgarian and Lithuanian students know very little about each other's countries and culture.

Key words: Bulgarians, collective identity, Lithuanians, religiosity 